\title{
IN MEMORY OF BRUCE SMITH
}

\author{
Gaetano Antinolfi \\ Washington University
}

Bruce Smith was a brilliant economist who made important contributions in several fields, most notably monetary and financial economics, monetary history, economic growth, business cycle theory, and development economics. Bruce was a prolific author with nearly 100 published papers and about a dozen unpublished papers. I will try in this short article to describe his way of doing economics and being an economist. Even though Bruce's research agenda was wide, his distinctive style was clear on every page of his writings.

There is one particular aspect of Bruce's research that I regard as his landmark contribution: the explicit, joint modeling of real and credit markets in a general equilibrium setting. Bruce also believed that money markets are intrinsically a part of credit markets and therefore they, too, constitute an integral aspect of macroeconomic analysis. Hence it is this triad-real economy, financial markets, and money markets - that forms the foundation of Bruce's economics.

Bruce loved history, and he loved to study both economic history and the historically important books of our profession. He wanted to make sense of them, taking economic theory seriously. That often meant, with his character, taking on the challenge of established propositions. He created, to give just a few examples, environments in which he could interpret important episodes in the history of money and banking; test logically when the Friedman rule is optimal and when it is not; show that the superneutrality of money easily fails in macroeconomic models with money and credit markets; and show that the real effects of changes in the rate of inflation depend on its initial level. Bruce cared deeply about economic development, and often applied his models to the study of developing economies. His work reflects his strong belief that both financial and monetary factors are crucial for economic development.

The creativity that Bruce brought to his work represents a wonderful side of his approach to being a scientist. His models have a distinctive style that Tim Kehoe once described as "the Bruce Smith style of applied economic theory." In spite of the often highly complex nature of the models, results are intuitive and insightful, and bring important concepts from economic theory in touch with economic policy. Two traits of Bruce's character are most important in understanding this style. One is prudence. Bruce would simply not yield easily to conclusions. The other is a strong passion for policy. In every aspect of his work, Bruce was seeking to make

I would like to thank Valerie Bencivenga, Todd Keister, and Karl Shell. Address correspondence to: Gaetano Antinolfi, Department of Economics, Campus Box 1208, Washington University, One Brookings Drive, St. Louis, Missouri 63130-4899, USA; e-mail: gaetano@wueconc.wustl.edu. 
important statements about economic policy. One of the last times I saw him, in St. Louis, we were discussing the generalization of a model of his, which was taking us into more and more abstract grounds. Bruce paused and smiled, and he kindly said, "Remember, ultimately we would like to be able to say something interesting about economic policy."

Bruce was, with Karl Shell, the co-chair of my dissertation committee at Cornell. Therefore, I was lucky enough to witness firsthand and benefit from Bruce's famous devotion to his students and their work. In fact, I would like to broaden this view, and emphasize that more generally Bruce was naturally devoted to the young. And the younger one was, the easier it was to connect with Bruce: those of us who saw Bruce playing with three-year-olds can just smile at this point. As for young economists, so many at the beginning of their careers benefited crucially from Bruce's input. His satisfaction was in being able to help those who were eager, younger, and less experienced than he was. Like all great scholars he had high standards, and he applied them more severely to the old than to the young. Three years ago, witnessing the amount of time and energy that Bruce dedicated to us, I felt embarrassment, and I told him so. Bruce replied to me that when he was a young Ph.D. (a one-year-old, as he liked to say), he had been lucky in meeting senior members of the profession who challenged him, coached him, and became his mentors and then his friends. He said to me, "Please don't worry, I am just giving back what I received and doing what I was taught to do."

Bruce was by nature positive and encouraging. He had a great attitude and he always thought he had been lucky. I saw him for the last time in Austin at the beginning of June 2002. Bruce was not feeling well; medical complications and treatments that he mentioned dismissively must have been taking their toll. In spite of this, he wanted to meet with Todd Keister and me to discuss a project the two of us were working on. Later on, I received an e-mail in which he encouraged us to pursue our project and apologized once more because he had not been well enough to socialize outside work. This was Bruce.

I remember vividly when in his office, in January of 1995, he told me he had cancer. Over the years I must have come up with the subconscious idea that he was invincible. Bruce's death leaves a huge void in the profession. He set an example of professional rigor for us to live by, and we will follow it, trying all the while to keep his positive spirits and, if we ever can, match his boundless energy.

We will always miss Bruce. Valerie Bencivenga, his wife, will miss him the most, and all our thoughts are with her. 